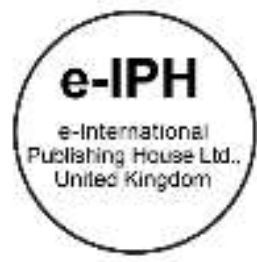

\title{
Employers' Perceptions in Hiring Decisions Pertaining to People with Disability
}

\author{
Norhayati Mat Yusoff ${ }^{1}$, Sofia Sarmimi Saripin ${ }^{1}$, Rosmaliza Muhammad ${ }^{2}$, Agus Sudono ${ }^{3}$ \\ 1 Department of Food Service Management, ${ }^{2}$ Department of Culinary Arts \& Gastronomy, \\ Faculty of Hotel and Tourism Management, Universiti Teknologi MARA, Puncak Alam Campus, 43200 Selangor, Malaysia. \\ ${ }^{3}$ Catering Industry Management Program and Tourism Department, \\ Universitas Pendidikan Indonesia, Jl. Dr. Setiabudhi No 229 \\ Bandung, Indonesia.
}

norhayati.my@uitm.edu.my, sofiasaripin@gmail.com, rosmaliza35@uitm.edu.my, sudono@upi.edu Tel Author1: +6012-3442042

\begin{abstract}
This study aims to analyze hotels employers' perceptions in hiring decisions on people with disability (PWD). A total of 35 samples out of 72 employers among the 4 and 5-star hotels in Kuala Lumpur were selected based on the census sampling method. It is found that employer perceptions to hire PWDs are influenced by gender, type of disability, work performance concerns, and co-worker and guest concerns. Interestingly, employers are discovered to have more positive perceptions towards female PWDs. They are also interested to hire PWDs who meet the requirements of the job regardless of their disability.
\end{abstract}

Keywords: Employers' perceptions; hiring decisions; people with disability; hotel industry.

eISSN: 2398-4287@ 2021. The Authors. Published for AMER ABRA CE-Bs by e-International Publishing House, Ltd., UK. This is an open access article under the CC BYNC-ND license (http://creativecommons.org/licenses/by-nc-nd/4.0/). Peer-review under responsibility of AMER (Association of Malaysian Environment-Behaviour Researchers), ABRA (Association of Behavioural Researchers on Asians/Africans/Arabians) and CE-Bs (Centre for Environment-Behaviour Studies), Faculty of Architecture, Planning \& Surveying, Universiti Teknologi MARA, Malaysia.

DOI: https://doi.org/10.21834/ebpj.v6i17.2817

\subsection{Introduction}

Employment in the hotel sector usually needs to have experienced workers to work in several departments, but the challenges and responsibilities of employers are to retain the workers (Joppe, 2012). Besides that, high employee turnover is the major problem in the hospitality industry (Emiroğlu, Akova, \&Tanrıverdi, 2015; Nor, Noor, Ahmad, Khalid, \& Ibrahim, 2017; Yao, Qiu, \& Wei, 2019). As an alternative, hiring people with disabilities can help employers since people with disabilities exhibit lower turnover rates and loyal and dependable employees who also perform on par with non-disabled employees. According to the Malaysian Disability Act $(2008 ; 9)$ People with disabilities (PWDs) are defined as "those who have long term physical, mental, intellectual or sensory impairments; which in interaction with various barriers may hinder their full and effective participation in society".

Yusof, Alib, and Salleh (2015) mentioned that negative perceptions of employers and the social community towards PWDs have indirectly impacted on employment opportunities of the PWDs. According to the Ministry of Human Resources in 2010, more than 95\% of PWDs in Malaysia were unemployed. They are capable and willing to work with employment opportunities (Ta \& Leng, 2013). Studies have exposed that the employment of disabled is still difficult and their participation in the employment is limited (Khoo et al., 2013a; Khoo, Tiun \& Lee, 2013b; Ta \& Leng, 2013). To date, there is little study about PWDs employment of hotel industry in Malaysia. Hence,

eISSN: 2398-42870 2021. The Authors. Published for AMER ABRA cE-Bs by e-International Publishing House, Ltd., UK. This is an open access article under the CC BYNC-ND license (http://creativecommons.org/licenses/by-nc-nd/4.0/). Peer-review under responsibility of AMER (Association of Malaysian Environment-Behaviour Researchers), ABRA (Association of Behavioural Researchers on Asians/Africans/Arabians) and CE-Bs (Centre for Environment-Behaviour Studies), Faculty of Architecture, Planning \& Surveying, Universiti Teknologi MARA, Malaysia.

DOI: https://doi.org/10.21834/ebpj.v6i17.2817 
objectives of this study is to determine the significant factors of employers' perceptions to hire and examine the relationship between employers' perceptions to hire people with disabilities (PWD) and employers' hiring decisions at 4 and 5 star hotel in Kuala Lumpur.

\subsection{Literature Review}

\subsection{Employer's Perception towards the Employment of PWDs}

Employer's perception is one of the miserable employment rates of PWDs (Heera \& Devi, 2016; Marumoagae, 2012; Zappella \& Dovigo, 2014). Employers who hold a negative perception towards the employment and presence of PWDs in the workplace (Gustafsson, Peralta \& Danermark, 2013; Huang \& Chen, 2015) could create barriers for them to hire the PWDs. Besides, the decreasing number of these people in the workforce is related to their attitudes and perceptions toward themselves. In some countries, working-age women found it difficult to enter the workforce (Ang, 2017). Women with disabilities generally have more negative working experiences like harassment, demanding and hazardous workplace, greater work demands, and higher levels of job insecurity. Furthermore, compared to disabled men, disabled women have lower employment rates and face many employment problems than men (Ang, 2017; Traustadottir, 1990). On the contrary, disabled men are less favorably than disabled women.

PWDs have been categorized into several types and employers' perception towards them depends on the type of disabilities (Baldwin \& Choe, 2014; Gustafsson et al., 2013; Mik-Neyer, 2016; Naraine \& Lindsay, 2011). According to Heera and Devi (2016), physically or mentally disabled people are less likely to be hired by employers. People who are blind, low vision, or psychiatric disabilities (Wiegand, 2008) are believed to have a lack of integration and participation at the workplace (Mik-Neyer, 2016; Naraine \& Lindsay, 2011). Employers are more likely to hire people with visible disabilities than those with deafness or psychiatric disabilities (Heera \& Devi, 2016).

Work performance concerns influence employers' attitude and perception to hire PWDs because PWDs are less productive (Bengisu \& Balta, 2011) and, sometimes job requirements might create stereotypical attitudes towards PWDs. Heera and Devi (2016) found that employers are worried about the work performance of those PWDs. Absenteeism, sick leaves, and leaves for doctors' appointments could affect their work performance. Instead, Kang (2013), Gustafsson, Peralta, \& Danermark, (2014) initiated that employers will hire PWDs who have a positive attitude, reliable, and are qualified with the job requirements.

Co-worker and customer reactions towards PWDs influence the employer's perception and decision to hire PWDs in their organization. Direct contact with the customers and customer's negative reaction to the PWDs will indirectly impact the organization (Kang, 2013). Employers' perception also lies in how co-workers and customers behave and communicate with those workers with disabilities. Kang (2013) stated that PWDs will have difficulty in serving customers directly and understanding the sensitivity of customers towards disability.

\subsection{Employer's Hiring Decisions towards the Employment of PWDs}

There are inconsistencies between the employer's hiring willingness and the actual hiring process. Copeland, Chan, Bezyak, and Fraser (2010) reported that there are positive attitudes toward PWDs among employers, but negative attitudes that appear towards the degree of comfort working with them will affect the actual hiring decision by employers. However, other studies have shown that employers who possess experience working with PWDs had favorable attitudes and decide to hire other PWDs in the organization (Heera \& Devi, 2016). Big companies/businesses, usually hired PWDs but no proof indicates the small business is unwilling in hiring people with disabilities.

Overall, there are four hypotheses for this study which are employer's perception of the gender of people with disabilities has a significant relationship towards the employer's hiring decisions. Employer's perception on type of disability of people with disability has a significant relationship towards employer's hiring decisions, employer's perception on work performance concerns of people with disability has a significant relationship towards employer's hiring decisions and employer's perception on a co-worker and guest concerns of people with disability has a significant relationship towards employer's hiring decisions.

\subsection{Methodology}

A Quantitative approach using a self-administered questionnaire survey was applied in this study to collect the data. Overall, there are 326 units of 4- and 5-star hotels in Malaysia was, but then the researcher only chose 72 units of 4- and 5-star hotels in Kuala Lumpur as the setting of the study because the number of 4- and 5-star hotels in Kuala Lumpur was higher than any other states in Malaysia. This study used the Census sampling method because the number of populations was small. Therefore, 35 Human Resource Manager and other managers (head of departments and executive members) who held the title and authority in hiring people in 4- and 5-star hotels in Kuala Lumpur, Malaysia involved in the data collection. Before the actual survey, respondents were contacted via telephone and electronic email to obtain their permission to conduct the survey process. Once the researcher has gotten the approval, the structured questionnaire based on five-point Likert scales ranging 1 "Strongly Disagree" 2 "Disagree" 3 "Neutral" 4 "Agree" and 5 "Strongly Agree" was distributed to the respective managers through email given by the human resource manager in the month of March 2020. However, due to the Coronavirus 2019 (Covid-19) pandemic that started to spread in Malaysia and worldwide in early February 2020, most of the hotels closed their business operation (until further notice) due to the obligation of Movement Control Order imposed by the government that started on 18 March 2020. The only channels that the researcher could reach the respondents were by electronic email and phone call instead of distributing personally. The researcher followed up every two weeks. With the limited access to collect data due to the implementation of MCO, the researcher got slow feedback and most of the managers were unable to participate in the survey as they 
were asked to work from home and had limited access to the internet (email). At the same time, some heads of departments and executive members of the hotel refused to participate and handed it over to HRM to answer the questions.

Although the follow-up was done every two weeks, the researcher only managed to get 35 responses or returned questionnaires. A pilot test also been conducted among 10 respondents from a 4-and 5-star hotel in Kuala Lumpur in February 2020) by using the link of google form through email. Data were analyzed using SPSS software version 22 for descriptive statistics and inferential statistics (multiple linear regression and Pearson coefficient analysis).

4.0 Results And Discussion

Using descriptive statistics, the overall dimension of the respondent's profile was analysed and reported in Table 4.1.

Table 4.1: Respondents' Profile

\begin{tabular}{|c|c|c|}
\hline Items & $\begin{array}{l}\text { Frequencies } \\
(\mathrm{N}=35)\end{array}$ & $\begin{array}{l}\text { Percentage } \\
(\%)\end{array}$ \\
\hline \multicolumn{3}{|l|}{ Gender } \\
\hline Male & 20 & 57.1 \\
\hline Female & 15 & 42.9 \\
\hline \multicolumn{3}{|l|}{ Age } \\
\hline $25-30$ & 1 & 2.9 \\
\hline $31-36$ & 18 & 51.4 \\
\hline $37-42$ & 14 & 40.0 \\
\hline $43-48$ & 2 & 5.7 \\
\hline \multicolumn{3}{|l|}{ Education level } \\
\hline Diploma & 2 & 5.7 \\
\hline Certificate (in related field) & - & - \\
\hline Degree & 19 & 54.3 \\
\hline Master & 14 & 40.0 \\
\hline \multicolumn{3}{|l|}{ Job title (Position) } \\
\hline Director of Communications & 1 & 2.9 \\
\hline HR Assistant & 1 & 2.9 \\
\hline Human Resources Manager & 32 & 91.4 \\
\hline Learning and Development Manager & 1 & 2.9 \\
\hline \multicolumn{3}{|l|}{ Years of experience (hotel industry) } \\
\hline 1 year -5 years & 4 & 11.4 \\
\hline 6 years -10 years & 14 & 40.0 \\
\hline 11 years and above & 17 & 48.6 \\
\hline \multicolumn{3}{|l|}{ Years of experience (current hotel) } \\
\hline 1 year -5 years & 24 & 68.6 \\
\hline 6 years -10 years & 9 & 25.7 \\
\hline 11 years and above & 2 & 5.7 \\
\hline \multicolumn{3}{|c|}{ Organization size (number of employees) } \\
\hline Small $(1-70)$ & - & - \\
\hline Medium $(71$ - 101) & 4 & 11.4 \\
\hline Large (102 and above) & 31 & 88.6 \\
\hline \multicolumn{3}{|c|}{$\begin{array}{l}\text { Have you ever employed people with } \\
\text { disability (PWD) in your organization? }\end{array}$} \\
\hline No & 20 & 57.1 \\
\hline Yes & 15 & 42.9 \\
\hline
\end{tabular}

It is interesting to reveal the answers for the question "Have you ever employed people with disability (PWD) in your organization?", 20 respondents $(57.1 \%)$ had no experience while 15 respondents (42.9\%) had experience hiring PWDs in their hotel. In short, this happened because the managers did not have the knowledge and awareness about hiring PWDs. 


\section{Employer's Perception on Gender of People with Disability}

Table 4.2: Mean Score of Employer's Perception on Gender of PWDs

\begin{tabular}{clll}
\hline No. & Items & Mean & Std. Deviation (SD) \\
\hline 1. & $\begin{array}{l}\text { Male with disability is absent less often than female } \\
\text { with disability. }\end{array}$ & 2.06 & 0.765 \\
2. & $\begin{array}{l}\text { Female with disability usually quits the job sooner } \\
\text { than male with disability. }\end{array}$ & 2.77 & 0.877 \\
3. & $\begin{array}{l}\text { Male with disability needs close supervision than } \\
\text { female with disability. }\end{array}$ & 3.17 & 0.954 \\
4. & $\begin{array}{l}\text { Female with disability usually turns out work of higher } \\
\text { quality than male with disability. }\end{array}$ & 3.54 & 0.980 \\
M. & $\begin{array}{l}\text { Male with disability is usually loyal to the companies } \\
\text { they work for than female with disability. }\end{array}$ & 2.37 & 0.942 \\
\hline
\end{tabular}

Employers had favourable and unfavourable perception towards gender differences of PWD. It showed that male with disability is absent often and quits the job sooner than female with disability. Employer's perception on male with disability needs close supervision than female with disability which was neutral $(M=3.17, S D=0.954)$. Employers also have somewhat favourable and unfavourable attitude towards female with disability who usually turns out work of higher quality than male with disability $(M=3.54 ; S D=0.980)$. Nevertheless, the results showed that employer's perception on male with disability is usually loyal to the companies they work for than female with disability which was unfavourable $(M=2.37$; $S D=0.942)$. Overall, most of the employers had more favourable perception towards female with disability than male with disability.

\section{Employer's Perception on Type of Disability of PWDs}

Table 4.3: Mean Score of Employer's Perception on Type of Disability of PWDs

\begin{tabular}{llll}
\multicolumn{4}{c}{ Table 4.3: Mean Score of Employer's Perception on Type of Disability of PWDs } \\
\hline No. & Items & Mean & SD \\
\hline 1. & $\begin{array}{l}\text { I will hire the most appropriate type of disability } \\
\text { based on the requirement of the job. }\end{array}$ & 4.37 & 0.690 \\
2. & $\begin{array}{l}\text { As an employer, I should hire anyone who meets } \\
\text { employment standards regardless of their disability. }\end{array}$ & 4.26 & 0.852 \\
I perceive learning disabilities applicants as more & 4.14 & 0.879 \\
3. & $\begin{array}{l}\text { Employable than other type of disability. } \\
\text { Exployees with hearing impairment accomplish }\end{array}$ & 4.06 & 0.938 \\
$5 . \quad$ & $\begin{array}{l}\text { I feel people with speech impairment are more } \\
\text { dependable than people without disabilities. }\end{array}$ & 4.11 & 0.900 \\
\hline
\end{tabular}

Most employers agreed that they will hire the most appropriate type of disability based on the requirement of the job $(M=4.37$; $S D=$ 0.690). Moreover, it showed that employers have favorable attitude in hiring PWDs who meet employment standards regardless of their disability $(M=4.26 ; S D=0.852)$. Hence, most employers agreed that they will hire PWDs who meet the specification of the job in accordance to their type of disability. It was supported when employers were asked about their perception on a specific type of disability which were learning disability, hearing impairment and speech impairment.

Employers showed favorable attitude in hiring learning disabilities applicants as compared to other types of disability $(M=4.14 ; S D$ $=0.879$ ). It can also be seen with hearing impairment employees where employers agreed that employees with hearing impairment accomplished extraordinary tasks despite their disability $(M=4.06 ; S D=0.938)$. Unfortunately, employers agreed that people with speech impairment are more dependable than people without disabilities $(M=4.11 ; S D=0.900)$.

\section{Employer's Perception on Work Performance of PWDs}

Table 4.4: Mean Score of Employer's Perception on Work Performance of PWDs

\begin{tabular}{|c|c|c|c|}
\hline No. & Items & Mean & SD \\
\hline 1. & $\begin{array}{l}\text { I am concerned about work performance of people with } \\
\text { disability. }\end{array}$ & 4.51 & 0.612 \\
\hline 2. & $\begin{array}{l}\text { People with disabilities will usually have low work } \\
\text { performance specifically in the areas of consistency in } \\
\text { task. }\end{array}$ & 2.77 & 1.114 \\
\hline 3. & $\begin{array}{l}\text { I believe that proper training can help people with } \\
\text { disability to increase their job productivity. }\end{array}$ & 4.60 & 0.604 \\
\hline 4. & $\begin{array}{l}\text { Employees with disabilities are absent less often than } \\
\text { people without disabilities. }\end{array}$ & 4.23 & 0.770 \\
\hline 5. & $\begin{array}{l}\text { Employees with disabilities tend to have better } \\
\text { punctuality records in term of completing a task. }\end{array}$ & 3.89 & 0.832 \\
\hline
\end{tabular}


Most employers agreed that they were concerned about work performance of people with disability $(M=4.51 ; S D=0.612)$. Employers disagreed that people with disabilities will usually have low work performance specifically in the areas of consistency in task $(\mathrm{M}=2.77$; $S D=1.114)$ because they believed that proper training can help people with disability to increase their job productivity $(M=4.60 ; S D=$ 0.604). With regard to employees with disabilities who were absent less often than people without disabilities, employers showed favourable perception $(M=4.23 ; S D=0.770)$. Concisely, PWDs had a good record in terms of their absenteeism as compared to their non-disabled worker. Briefly, employer's negative perception towards work performance of PWDs can be deterred with providing a proper training for them, as the mean score for the item "I believe that proper training can help people with disability to increase their job productivity" ( $M=4.60 ; S D=0.604)$ was the highest than other items in the questionnaire.

\section{Employer's Perception on Co-workers and Guest Concerns towards PWDs}

Table 4.5: Mean Score of Employer's Perception on Co-workers and Guest Concerns Towards PWDs

\begin{tabular}{|c|c|c|c|}
\hline No. & Items & Mean & SD \\
\hline 1. & $\begin{array}{l}\text { Co-workers who express concern about the work } \\
\text { performance of employees with disabilities will affect my } \\
\text { perception in hiring people with disabilities. }\end{array}$ & 3.80 & 0.719 \\
\hline 2. & $\begin{array}{l}\text { Guest's negative reaction to people with disabilities which } \\
\text { may impact the organization's bottom line will affect my } \\
\text { perception in hiring people with disabilities. }\end{array}$ & 4.11 & 0.676 \\
\hline 3. & $\begin{array}{l}\text { The entry of people with disabilities in the workforce may } \\
\text { affect the motivation of their non-disabled counterparts; } \\
\text { thus, influence my perception in hiring them. }\end{array}$ & 3.66 & 0.906 \\
\hline 6. & $\begin{array}{l}\text { Employees with disabilities make other employees } \\
\text { uncomfortable to work with them. }\end{array}$ & 2.66 & 1.235 \\
\hline
\end{tabular}

Co-workers who expressed concern on the work performance of employees with disabilities will affect the perception in hiring PWDs (M $=3.80, \mathrm{SD}=0.719$ ). Somehow employer's perception to hire PWDs will be affected by concerns from non-disabled employees. Nonetheless, employers agreed that guest's negative reaction to PWDs will also affect their perception in hiring PWDs ( $M=4.11 ; \mathrm{SD}=$ 0.676). The figure also showed that employer's perception to hire was more affected or influenced by guest concern rather that coworkers' concerns. Then, pertaining to the concern of employees towards their motivation to work with PWDs also did not affect the perception of employers to hire PWDs. Employer's perception towards co-workers who expressed the entry of PWDs in the workforce may affect their motivation as it fell into neutral $(M=3.66 ; S D=0.906)$ while employers disagreed that PWDs will make co-workers feel uncomfortable to work ( $M=2.66 ; S D=1.235$ ). Overall, employer's perception to hire PWDs was somehow affected by co-workers and guest concerns particularly in the area of provision of accommodation, morale and productivity and communication.

\section{Employer's Hiring Decision to Hire PWDs}

Table 4.6: Mean Score of Employer's Perception on Co-workers and Guest Concerns Towards PWDs

\begin{tabular}{|c|c|c|c|}
\hline No. & Items & Mean & SD \\
\hline 1. & $\begin{array}{l}\text { I have the authority to hire someone whether they are disabled or } \\
\text { normal as an employee. }\end{array}$ & 4.23 & 1.087 \\
\hline 2. & $\begin{array}{l}\text { If I wanted to, I could hire a person with disability for a job in the } \\
\text { organization. }\end{array}$ & 3.74 & 0.919 \\
\hline 3. & I will hire people with disabilities if there is an opportunity to do so. & 4.51 & 0.507 \\
\hline 4. & $\begin{array}{l}\text { I will actively seek out people with disabilities to work in my } \\
\text { company. }\end{array}$ & 4.03 & 0.618 \\
\hline
\end{tabular}

Most of the employers had the authority to hire someone whether they are disabled or normal as an employee $(M=4.23 ; S D=1.087)$, but they were in neutral position in hiring a PWD for a job in the organization $(M=3.74 ; S D=0.919)$ due to the organization's policy. In addition, employers agreed that they will hire people with disabilities $(M=4.51 ; S D=0.507)$ and will actively seek out PWDs to work in their company ( $M=4.03 ; S D=0.618$ ) if there is an opportunity to do so. This is in line with the previous study by Yusoff, Darimi, Zahari, Mustapha and Ghani (2016), revealed that it is worth for the fast food restaurants to have people with disability (PWD) as they are having positive attitudes, obedience, easy to manage as well as committed and loyal. The relationship between gender, type of disability, work performance concerns, and co-workers and guest concerns towards employer's hiring decision was analysed using Pearson correlation.

All hypotheses were supported and there was a medium correlation between employer's perception on gender of people with disability towards employer's hiring decisions as given by the $r$ value $(r=0.435$,) which indicated a quite strong relationship between gender of people with disability and employer's hiring decisions with significant value $p=0.005<0.05$. There was a large correlation between employer's perception on type of disability of people with disability towards employer's hiring decisions $(r=0.632, p=0.000<$ 0.05). Meanwhile, there was a medium correlation between employer's perception on work performance concerns of people with disability towards employer's hiring decisions $(r=0.427 . p=0.005<0.05)$ which indicated there was a quite strong relationship between work performance concerns and employer's hiring decisions. Lastly, there was significant relationship towards employer's hiring decisions $(r$ 
$=0.631, p=0.000<0.05)$ which indicated a strong relationship between co-worker and guest concerns and employer's hiring decisions. All hypotheses are significant.

Table 4.7: The hypothesis of gender, type of disability, work performance concerns, and co-workers and guest concerns.

\begin{tabular}{|l|l|l|l|l|}
\hline Indicator & Hypothesis & $\begin{array}{l}\text { Pearson } \\
\text { Correlation }(r)\end{array}$ & $p$-value $(p<0.05)$ & Remarks \\
\hline H1a & $\begin{array}{l}\text { Employer's perception on gender of people with } \\
\text { disability has significant relationship towards } \\
\text { employer's hiring decisions. }\end{array}$ & 0.435 & 0.005 & Supported \\
\hline H1b & $\begin{array}{l}\text { Employer's perception on type of disability of } \\
\text { people with disability has significant relationship } \\
\text { towards employer's hiring decisions. }\end{array}$ & 0.632 & 0.000 & Supported \\
\hline H1c & $\begin{array}{l}\text { Employer's perception on work performance } \\
\text { concerns of people with disability has significant } \\
\text { relationship towards employer's hiring decisions. }\end{array}$ & 0.427 & 0.005 & Supported \\
\hline H1d & $\begin{array}{l}\text { Employer's perception on co-worker and guest } \\
\text { concerns of people with disability has significant } \\
\text { relationship towards employer's hiring decisions. }\end{array}$ & 0.631 & 0.000 & Supported \\
\hline
\end{tabular}

\section{Multiple Linear Regression Analysis}

\begin{tabular}{|c|c|c|c|c|c|}
\hline \multicolumn{6}{|c|}{ Table 4.8: Model Summaryb } \\
\hline Model & $\mathrm{R}$ & R Square & Adjusted R Square & $\begin{array}{l}\text { Std. Error of the } \\
\text { Estimate }\end{array}$ & Durbin-Watson \\
\hline 1 & $.831^{\mathrm{a}}$ & .690 & .649 & .329 & 2.548 \\
\hline
\end{tabular}

A large correlation between employer's perception on co-worker and guest concerns of people with disability since it had a for this analysis, the R2 value is 0.690 which means $69.0 \%$ of the variation in employer's decision to hire (DV) can be explained by the dimensions of employer's perception (IV) which are gender, type of disability, work performance concerns and co-workers and guest concerns.

\subsection{Conclusion}

Employer's perception which includes perception on gender of disabled worker, perception on type of disability of the disabled worker, perception on work performance of the disabled worker and perception on co-workers and guest concern towards the disabled worker have significant relationship towards employer's hiring decision. Employer's perception on type of disability of PWDs is the most important dimension to measure employer's perception towards their hiring decision. This study emphasizes an insight to the hotel's employers that people with disability are loyal and committed towards their job. It also helps other managers to understand and value the disabled worker like their non-disabled colleagues and to create awareness about the benefits of hiring people with disability. Future research can also look into the challenges faced by the employers when having disabled worker in their organization instead of focusing on employer's perception and their hiring decision.

\section{References}

Ang, M. C. H. (2017). Employers' Perceptions of Persons with Disabilities: Evidence of Gender Differences. Journal of Management and Marketing Review, 2(1), 1-7.

Baldwin, M. L., \& Choe, C. (2014). Re-examining the Models Used to Estimate Disability-Related Wage Discrimination. Applied Economics, 46(12), 13931408 .

Bengisu, M., \& Balta, S. (2011). Employment of the Workforce with Disabilities In The Hospitality Industry. Journal of Sustainable Tourism, 19(1), 35-57.

Copeland, J., Chan, F., Bezyak, J., \& Fraser, R. T. (2010). Assessing Cognitive and Affective Reactions of Employers toward People with Disabilities in the Workplace. Journal of Occupational Rehabilitation, 20(4), 427-434.

Emiroğlu, B. D., Akova, O., \& Tanrıverdi, H. (2015). The Relationship between Turnover Intention and Demographic Factors in Hotel Businesses: A Study at Five Star Hotels in Istanbul. Procedia-Social and Behavioral Sciences, 207, 385-397.

Gustafsson, J., Peralta, J. P., \& Danermark, B. (2014). The Employer's Perspective: Employment of People with Disabilities in Wage Subsidized Employments. Scandinavian Journal of Disability Research, 16(3), 249-266. 
Heera, S., \& Devi, A. (2016). Employers' Perspective towards People with Disabilities: A Review of the Literature. The South East Asian Journal of Management.

Huang, I. C., \& Chen, R. K. (2015). Employing People with Disabilities in the Taiwanese Workplace: Employers' Perceptions and Considerations. Rehabilitation Counseling Bulletin, 59(1), 43-54.

Joppe, M. (2012). Migrant Workers: Challenges and Opportunities in Addressing Tourism Labour Shortages. Tourism Management, 33(3), 662-671.

Kang, D. (2013). Why Would Companies Not Employ People with Disabilities in Korea? Asia Pacific Journal of Social Work and Development, 23(3), $222-229$.

Khoo, S. L., Tiun, L. T., \& Lee, L. W. (2013a). Unseen Challenges, Unheard Voices, Unspoken Desires: Experiences of Employment by Malaysians with Physical Disabilities. Kajian Malaysia, 31(1), 37.

Khoo, S. L., Tiun, L. T., \& Lee, L. W. (2013b). Workplace Discrimination against Malaysians with Disabilities: Living with It or Fighting Against It? Disability Studies Quarterly, 33(3).

Malaysian Disability Act (2008). Circular No. 3 of 2008, Public Service Department, Malaysia.

Marumoagae, M. C. (2012). Disability Discrimination and the Right of Disabled Persons to Access the Labour Market. Potchefstroom Electronic Law Journal/Potchefstroomse Elektroniese Regsblad, 15(1).

Mik-Meyer, N. (2016). Disability and 'Care': Managers, Employees and Colleagues with Impairments Negotiating the Social Order of Disability. Work, Employment and Society, 30(6), 984-999.

Nor, M. N. M., Noor, A. N. M., Ahmad, Z., Khalid, S. A., \& Ibrahim, I. I. (2017). Factors Affecting Turnover Intention among Gen Y in Hotel Industry. Jurnal Intelek, 12(1).

Ta, T. L., \& Leng, K. S. (2013). Challenges Faced by Malaysians with Disabilities in the World of Employment. Disability, CBR \& Inclusive Development, 24(1), 6-21.

Traustadottir, R. (1990). Women with Disabilities: The Double Discrimination. Syracuse, NY: Center on Human Policy.

Yao, T., Qiu, Q., \& Wei, Y. (2019). Retaining Hotel Employees as Internal Customers: Effect of Organizational Commitment on Attitudinal and Behavioral Loyalty of Employees. International Journal of Hospitality Management, 76, 1-8.

N.M. Yusoff, S.N.A. Darimi, M.S.M. Zahari, N.A. Mustapha, F.A. Ghani (2016). Commitment and loyalty of the hearing impaired employees in the fast food restaurant: Heritage, Culture and Society (1st Ed.). Taylor Francis Group, London: CRC Press.

Zappella, E., \& Dovigo, F. (2014). A Job Good Enough: The Path to Workplace Inclusion in Small and Medium-Sized Companies in Northern Italy. In Conference Proceedings: The Future of Education (pp. 163-166). 